Beyond Kinsey: The Committee for Research on Problems of Sex and American Psychology.

\author{
Peter Hegarty \\ University of Surrey
}

\title{
Author Note:
}

Please direct correspondence to Peter Hegarty, Department of Psychology, University of Surrey, Guildford, GU2 7XH, UK, p.hegarty@surrey.ac.uk 
Beyond Kinsey: The Committee for Research on Problems of Sex and American Psychology.

Kinsey's midcentury surveys of male and female sexual behaviour are unquestionably pivots in the 'modernization of sex;' that shift from religious to psycho-medical authority over norms of human sexual conduct. ${ }^{\mathrm{i}}$ A quarter century later, sex became 'postmodernized' through mass consumption in late capitalist societies. ${ }^{\text {ii }}$ In that later moment, scholars increasingly began to think about 'sex' as a historical category, to be understood as something produced in discourse rather than a natural or psychological drive battling repression for its liberated expression. ${ }^{\text {iii }}$ Such histories have prompted further attention to the ways that accounts of the 'naturalness' of sex have been funded, organized, written and received in earlier modern moments.

In the beginning of the $21^{\text {st }}$ century, as in the middle of the $20^{\text {th }}$, 'Kinsey' is a name linked to 'sex' in public discourses in multiple ways that approach the mythic. Events such as the release of Bill Condon's biopic Kinsey and the publication of T.C. Boyle's roman a clef The Inner Circle have brought Kinsey and sex research back into public attention. ${ }^{\text {iv }}$ The Kinsey story can be narrated as romance - as in Condon's film, or as tragedy- as in Boyle's novel. ${ }^{\mathrm{v}}$ However, all narrations of Kinsey's research as a modern break with the past risk of erasing the sex research of the psychologists in the pre-Kinsey era. A return to the first chapter of Kinsey's Sexual Behavior in the Human Male (SBHM) suggests further reason to remember that moment in the history of psychology. Therein, Kinsey and his co-authors describe nineteen past studies of the sexual behaviour of Americans which were "(1) scientific, (2) based on more or less complete case histories, (3) based on series of at least some size, (4) involving a systematic coverage of approximately the same items on each subject, and (5) statistical in treatment.",vi Eleven of the studies were conducted by psychologists, by psychiatrists or by both. The Kinsey studies are certainly important turning 
points in the modernization story, but they are clearly not its opening scene. The following three short papers attend to researchers who were in conversation with Kinsey, but who all preceded him by some years in entering into the controversial domain of sex research.

Each of the research programs that we historicize was funded by the Committee for Research on Problems of Sex (CRPS), the primary funding source for sex research in the United States from 1921 until the Kinsey team began to consume half of its annual budget in the mid-1940s. Drawing on other excellent accounts, I will offer a re-telling of the committee's origins to contextualize the three papers. ${ }^{\text {vii }}$ Of course, the committee did not initiate sex research. In the early $20^{\text {th }}$ century, some early American psychologists such as G. Stanley Hall continued to write precociously about the dangers of sex, social hygienists had begun to conduct sex surveys to inform their battles against venereal and moral pollution, and psychoanalysis suggested to increasingly wider publics that unconscious sexual desires loomed large among humankind's basic motives. ${ }^{\text {viii }}$ The original idea for a committee that would support and organize sex research came from Earl Zinn, a former student of Hall's who worked as 'director of questionnaires' at the American Social Hygiene Association. In 1920, Social hygienists Max Exner and Katharine Bement Davis supported Zinn in taking forward his idea to John D. Rockerfeller Jr., who in turn supported Zinn's bringing it to psychologist Robert Yerkes, then Chairman of the Research Information Bureau of the National Research Council. Yerkes first presented Zinn's idea to the Division of Anthropology and Psychology, who rejected it. But Zinn's idea was supported by Victor Vaughn, the chair of the Medical Division of the NRC. As Pickren notes, the small multidisciplinary group who met in 1921 to consider Zinn's proposal included several prominent American psychologists; Robert Yerkes, Helen Woolley, Carl Seashore, and Walter Cannon. ${ }^{\text {ix }}$ 
Through the mid-1920s, the CRPS was funded by Rockerfeller through the Bureau for Social Hygiene. The committee was chaired by Yerkes and included Katharine Davis, Walter B. Cannon, Frank Lillie, and Thomas W. Salmon as members. This group was characterized by that form of 'modern' consciousness described by Latour. On the one hand, the CRPS was concerned to separate out a pure "nature" for sex, that could be studied objectively and apolitically. On the other, the committee effectively drew human, animals and technology into new networks of fact production that were neither purely natural or purely social. ${ }^{\mathrm{x}}$ Most obviously, the committee's work was characterized by a rhetoric of objectivity coupled with practices that brokered power and patronage among a few trusted and well-established researchers. The 'hit rate' for grant applicants was high, as almost every grant application was preceded by a conference to vet the researchers. ${ }^{\mathrm{xi}}$ The CRPS invested heavily in biological programs of research, creating enduring forms of naturalistic rhetorical about the hormonal determination of human sexual behaviour. ${ }^{\text {xii }}$ The animal models of Calvin Stone at Stanford and Robert Yerkes at Yale were the most obvious effects of this culture on psychology. Scholars such as Donna Haraway, Adele Clarke, and Wade Pickren have emphasized how such capital investments in animal research were fueled by the desire for a rational social engineering of human societies that was consistent with patriarchal capitalism. However, while investing heavily in animals, CRPS-funded scientists neglected the agency of the animals they caged in creating moral ambiguity within the category of 'natural' sexuality. Michael Pettit analyzes the slippage between observation and conclusion as researchers reacted different to rats who behaved queerly under conditions of laboratory confinement. Rat metaphors also implicitly threatened the heteronormative arrangements of Beach's own life, increasingly oriented around the lab rather than the home, as his attention became captivated by the disposable life in his colonies. 
The CRPS ventured its capital on behavioural research on human sexuality less often. However, Lewis Terman was rather exceptionally granted funds for the development of the test of 'Masculinity-Femininity' (M-F). Just prior to introducing the now-famous 7-point scale, Kinsey pointed to the Terman and Miles 1936 book Sex and Personality which introduced the M-F test to exemplify the erroneous preconception that sexual orientation can be read from embodied or behavioural gender inversion. In the second paper, Peter Hegarty focuses on Catharine Cox Miles', arguing that Miles' resisted Terman's theory of gender and ventured alternatives to it both in private and in print. Terman was quick to pen a critical review of SBHM for Psychological Bulletin. ${ }^{\text {xiii }}$ However, Miles' library research informed her views on sex survey research which accorded with Kinsey's, particularly in her admiration for the work of early women researchers in the field such as Clelia Mosher and Katherine Davis.

Of course, Terman was not the only psychologist to publish a reaction to Kinsey's research. Indeed, in 1948, Psychological Bulletin published two reviews of SBHM, the other being an earlier, shorter and more positive review by psychologist Carney Landis. ${ }^{\text {xiv }}$ Landis, work with Marjorie Bolles, on the sexuality of disabled women has been all but forgotten to history until David Serlin turned his attention to it here. Two of Landis works were among the nineteen studies that Kinsey reviewed in SBHM, and Landis and Bolles' book on disabled women was implicitly praised for adopting a non-pathologizing view of masturbation. ${ }^{\mathrm{xv}}$ Through a juxtaposition of Landis and Bolles book and the unpublished interviews with the disabled women, now archived in the Kinsey Institute, Serlin finds theoretical possibilities for a theory of sexuality that eludes the modernist homo/hetero binary.

Serlin suggests instead a 'counter history' of sex research in the interwar period whose arc runs from Katherine Bement Davis, through Landis and Bolles' to Kinsey’s surveys. Jointly these papers contribute to that counter history new narrative possibilities for 
thinking about the CRPS. Adele Clarke has described the CRPS as troubling Foucault's argument that sexology and the reproductive sciences have separate histories in modernism. ${ }^{\mathrm{xi}}$ Donna Haraway has similarly described the period of Robert Yerkes' influence in psychobiology as one in which sex and reproduction were closely aligned, in contrast to the later era in which Warren Weaver's theory of informatics made biology a science of communication, and made sex and reproduction strangers once again. ${ }^{\text {xvii }}$ In other words, both Clarke and Haraway narrate the Yerkes-lead CRPS as a moment where 'sex' and 'reproduction' were somewhat particularly co-constructive. By following Clarke and Haraway's advice to attend to gender and species boundaries in the history of science, all three of the histories presented here suggest that in myriad ways, 'sex' and 'reproduction' were much more precariously aligned and much more variously resisted in the research networks of the CRPS than previously recognized.

\footnotetext{
${ }^{\mathrm{i}}$ Alfred C. Kinsey, Wardell B. Pomeroy, and Clyde E. Martin. Sexual Behavior in the Human Male. Philadelphia: W. B. Saunders and Company, 1948; Alfred C. Kinsey, Wardell B. Pomeroy, Clyde E. Martin, and Paul Gephart. Sexual Behavior in the Human Female. Philadelphia: W. B. Saunders and Company, 1953. See also Paul A. Robinson. The Modernization of Sex. New York: Harper Collins, 1977.

ii David Harvey. The condition of postmodernity; An enquiry into the origins of cultural change. Cambridge, MA: Blackwell, 1990. For a compelling account of transformations in understandings of masturbation in postmodern societies see Thomas W Laqueur. Solitary Sex: A Cultural History of Masturbation. New York: Zone Books, 2003.

iii Michel Foucault. The History of Sexuality, Volume 1: An Introduction. Trans. Robert Hurley. New York, Vintage, 1978.
} 
${ }^{\text {iv }}$ T.C. Boyle. The Inner Circle. New York: Viking, 2004. Bill Condon, Director. Kinsey. Fox Searchlight Pictures, 2004;

${ }^{\mathrm{v}}$ For an insightful essay on the different narratives written into biographies of Alfred Kinsey see James H. Capshew, Matthew H. Adamson, Patricia A. Buchanan, Narisara Murray, and Naoko Wake. "Kinsey's Biographers: A Historical Reconnaissance." Journal of the History of Sexuality 12.3 (2003): 465-486. On narrative form in historiography see Hayden White.

Metahistory: The Historical Imagination in Nineteenth-Century Europe. Baltimore, MD: Johns Hopkins University Press, 1973.

${ }^{\text {vi }}$ Kinsey et al., SBHM, op. cit. 23.

${ }^{\text {vii }}$ See the 'internalist' history Sophie D. Aberle and George W. Corner. Twenty Five Years of Sex Research: History of the National Research Council Committee for Research in Problems of Sex 1922-1947. Philadelphia, PA: W.B. Saunders Company, 1953. For a more critical 'externalist' history see Adele E. Clarke, Disciplining Reproduction: Modernity, American Life Sciences, and the Problems of Sex Berkeley, CA: University of California Press, 1998. On the relevance of the CRPS to early animal research see Wade Pickren. Robert Yerkes, Calvin Stone and the Beginnings of Programmatic Sex Research by Psychologists, 1921-1930. American Journal of Psychology 110.4 (1997): 603-619. viii See Granville Stanley Hall. Adolescence: Its Psychology and Its Relation to Physiology, Anthropology, Sociology, Sex, Crime, Religion and Education, Vol. 1 and 2. New York: D. Appleton and Company, 1904. On early sex surveys among social hygienists see See Julia A. Ericksen. Kiss and Tell: Surveying Sex in the Twentieth Century. Cambridge, MA: Harvard University Press, 1999; Jeffrey P. Moran. Teaching Sex: The Shaping of Adolescence in the 20th Century. Cambridge, MA: Harvard University Press, 2000. On the popularity of psychoanalysis in the 1920s see Nathan G. Hale, Jr. The rise and crisis of psychoanalysis in the United States: Freud and the Americans, 1917-1985. Oxford: Oxford University Press. 
ix Pickren, "Robert Yerkes," op. cit.

${ }^{\mathrm{x}}$ Bruno Latour. We Have Never Been Modern. Cambridge, MA: Harvard University Press, 1993. On the relevance of this notion of purity to the history of psychology see Peter Hegarty. "Getting Dirty: Psychology's History of Power." History of Psychology 10.2 (2007): $75-91$.

${ }^{\mathrm{xi}}$ Aberle and Corner, op. cit.

${ }^{\text {xii }}$ See particularly Clarke, Disciplining, op. cit. For a critique of hormonal explanations of human sexual practices and a discussion of their continuing popularity see Anne FaustoSterling. Sexing the body: Gender politics and the construction of sexuality. New York: Basic Books, 2000.

xiii Lewis M. Terman. "Kinsey's 'Sexual Behavior in the Human Male': Some Comments and Criticisms." Psychological Bulletin 45.5 (1948): 443-59.

${ }^{\text {xiv }}$ Carney Landis. "Book Review: Kinsey, Pomeroy, \& Martin, Sexual Behavior in the Human Male." Psychological Bulletin 45.3 (1948): 272-275.

${ }^{\mathrm{xv}}$ Kinsey et al., SBHM, op. cit. 26-27, 514.

${ }^{\mathrm{xvi}}$ Clarke, Disciplining, op. cit.

${ }^{x v i i}$ Donna Haraway. Symians, Cyborgs and Women: The Reinvention of Nature. New York, Routledge, 1991. 